\title{
The Relevance of Physics Learning on the Vocational High School Students of Automotive Study Program
}

\author{
N N Laili ${ }^{1}$, M D Putra ${ }^{2}$ and B Astuti ${ }^{3}$ \\ ${ }^{1,2,3}$ Graduate School, Universitas Negeri Semarang, Indonesia \\ ${ }^{1}$ Corresponding email: nihlanurul@gmail.com
}

\begin{abstract}
Physics has become the foundation of vocational competence of vocational high school or Sekolah Menengah Kejuruan (SMK) in technology and engineering expertise. This research aimed to get information about the relevance of physics with the automotive learning in SMK of light vehicle techniques or Teknik Kendaraan Ringan (TKR) competence. This study was a qualitative research with the subjects students grade $\mathrm{X}$ of TKR class at three different SMKs in Pekalongan. The data were collected by conducting library research, tests, and interviews. The data obtained were analyzed qualitatively descriptive. The results of library research analysis on the physics basic competence of SMK in curriculum 2013 with the TKR basic competence indicated a relevance among them. Physics materials that were compatible with the TKR basic competence included measurement, Newton's law, work and energy, torque, elastisits properties, static and dynamic fluids, heat and temperature, thermodynamics, dynamic electricity, laws of magnetism, and alternating current circuits, while the incompatible physics material consisted of straight and circular motion, momentum, impulse, vibrations, and waves. Students physics test in three different SMK resulted has not yet reached a classical thoroughness. At last, the interviews with the automotive teachers indicated the relevance of students 'physics values with students' abilities in the automotive vocational practice.
\end{abstract}

Keyword: relevance, physics learning, automotive egineering

\section{Introduction}

The world is experiencing the era of the fourth industrial revolution or industry 4.0. The fourth industrial revolution has technological features that blend into society and the human body, robotics, quantum computing, automation of vehicles, virtual and physical systems working globally (Triyono, 2017). The advancement of science in the field of technology will reduce human as labor. The impact of the fourth industrial revolution is one of which reduces routine work or repetition of work (Sackey and Bester, 2016). The education sector, especially vocational high school, is the main focus for preparing qualified and highly competitive workforce. Therefore, learning in vocational schools should emphasize students' thinking skills rather than simply teaching routine skills.

Vocational Secondary Education is an education that equips students with scientific and technological skills and professional vocational skills in accordance with the needs of the community (PP number 17 year 2010). Physics is included in a group of adaptive or vocational subjects in Vocational High School (SMK). Physics subject is used to equip students' basic knowledge of natural laws and become conditions of ability to achieve the competence of the program of expertise
(Saolika et al, 2012). Through the basic knowledge of physics owned by students, it is expected that automotive vocational skills is not just trial and error. It is not just the skills that vocational school students need, but knowledge is also needed to be the basis for implementing those skills (Wheelahan, 2015).

Substance or materials taught in SMK are presented in the form of various competencies that are considered important and necessary for students to live their lives in accordance with the times. Such competence is required to be a smart Indonesian man and a competent worker, in accordance with the standards of competence established by industry/business world/professional associations (Jatmoko, 2013). In order to achieve the established standard of competence, the subjects are grouped and organized into three groups of normative, adaptive, and productive subjects (Permendikbud Number 64 Year 2013). Physics is a group of adaptive subjects so it is expected to focus more on providing opportunities to students to understand and master the basic concepts and principles of science and technology that can be applied to everyday life and underpin the competence to work.

The relevance of physics material with automotive competence is needed to see how far the picture of the interrelationship between 
the material because in the curriculum there must be relevance between the curriculum components. Whether or not the goal of vocational education is achieved is the relevance of the subject matter with the quality needs of the graduates. The principle of external relevance is the suitability between the curriculum and the demands and needs of society, while the principle of internal relevance is the suitability between the curriculum itself (Ibrahim, 2011). Research on external relevance has been done a lot of research results show the relevance of SMK curriculum competence of light vehicle techniques expertise to industrial needs in Sleman Regency (Jatmoko, 2013). In addition, the results of the study indicate that the basic competencies in the class XI SMK building engineering skill class of $38.89 \%$ drawing drawings are relevant to the work needs of the peasant consultant office (Maulana \& Winanti, 2016).

Research on the internal relevance of the SMK curriculum has not been done. Whereas internal relevance helps SMK teachers in giving special emphasis to materials that are related to vocational areas. Therefore, this study aimed to determine the relevance of physics learning in the students of the automotive study program of Vocational High School.

\section{Methods}

This study used qualitative method. Qualitative research is done under normal circumstances (natural setting) and the data collected are qualitative. Meanwhile, the data analysis technique used was descriptive qualitative.

This research was conducted in three vocational schools majoring in automotive in Pekalongan Regency in the academic year of 2017/2018. The subjects of the study were 99 students of $\mathrm{X}$ Class of Light Vehicle Techniques or Teknik Kendaraan Ringan (TKR). For more, the techniques of data collection were library research techniques, tests, interviews, and documentation.

Library research technique was done by identifying curriculum document of subject of Vocational physics and Light Vehicle Techniques subjects (TKR). From the results of identification of each basic competence TKR, it was known that the material of physics needed to be the basis in learning the theory and practice TKR. Therfore, it can be grouped in relevant physics material and not relevant to basic competence TKR.

The written test technique was realized in the form of multiple choice questions amounting to 20 questions. The test matter covered all the basic competencies of physics of class X TKR class which have been studied. The results of written tests were strengthened by conducting interviews to explore the level of students' physics understanding. To know the relevance of students' physics ability with automotive ability, the interviews with light vehicle techniques teachers were supported by documentation of automotive practice values in the odd semester.

\section{Results and Discussion}

Physics subject in SMK Department of Light Vehicle Techniques is included in the $\mathrm{C} 1$ group that is the basic group of areas of expertise. The group of productive subjects of light vehicle Techniques is grouped into two groups, namely $\mathrm{C} 2$ as the basic group of skill programs and $\mathrm{C} 3$ as the skills competency group. In the basic group of expertise there are two subjects namely basic automotive technology and basic automotive work, while in the skill competence group there are three subjects that are maintenance of light vehicle techniques, chassis maintenance and light vehicle power transfer, and maintenance of light electric vehicle.

The relevance of physics learning in automotive SMK was viewed in two ways, namely the relevance of physics material with basic competence of Light Vehicle Techniques (TKR) and the relevance of physics value with students' automotive ability.

\subsection{Relevance of Physics Material with Basic Competence of Light Vehicle Techniques (TKR)}

The subject of physics of SMK competence of Light Vehicle Techniques skill (TKR) 2013 curriculum consists of 14 basic competencies, namely: (1) applying the principles of measuring physical quantities, important figures and scientific notation in the field (3) analyzing motion and style using Newton's laws, (4) analyzing business relationships, energy, power and power, and (5) applying the concept of momentum, impulse and the law of conservation of momentum, (6) applying the concept of torque, 
moment of inertia, and angular momentum on rigid bodies in technology and engineering; (7) analyzing the strength of the material of its elasticity; apply laws relating to static and dynamic fluids, (9) analyzing vibrations, waves and sounds, (10) analyzing the expansion process, change the form of matter and heat transfer with the concept of temperature and heat, (11) applying the laws of thermodynamics, (12) applying static electricity and dynamic electricity, (13) applying the laws of magnetism in everyday problems, and (14) application of electric alternating current (AC) [10]. Based on the results of the library research and the results of interviews with automotive teachers obtained information that there is relevant physics material to learn the theory and practice of TKR and there is an irrelevant physics material to be studied in SMK competency skills TKR. The results of the relevant analysis of Vocational Physics materials that are irrelevant to the TKR practices are presented in Table 1 .

Table 1. Relevance of Physics Material

\begin{tabular}{clc}
\hline No & \multicolumn{1}{c}{ Physics Material } & Relevance \\
\hline 1 & Measurement of physical quantities & Relevance \\
2 & Straight motion and circular motion & Irrelevant \\
3 & Newton's Laws & Relevance \\
4 & Work, energy, power, and efficiency & Relevance \\
5 & Momentum, impulse, and law of conservation of momentum & Irrelevant \\
6 & Torque, moment of inertia, and angular momentum & Relevance \\
7 & Material elasticity & Relevance \\
8 & Fluid static and dynamic & Relevance \\
9 & Vibrations, waves, and sounds & Irrelevant \\
10 & Temperature and heat & Relevance \\
11 & The laws of thermodynamics & Relevance \\
12 & Electricity is static and dynamic & Relevance \\
13 & The laws of magnetism & Relevance \\
14 & Electricity of alternating current (AC) & Relevance \\
\hline
\end{tabular}

In the subjects of basic automotive technology, relevant physical materials are energy, fluid, temperature, heat, thermodynamics, and dynamic electricity. In the subject of basic automotive work required physical material which includes measurement, Newton's law, effort, torque, and fluid. On the subject of maintenance of a light vehicle engine requires a physical material which includes measurement, Newton's law, effort, energy, power, efficiency, torque, fluid, temperature and heat, and thermodynamics. On the subject of chassis maintenance and light vehicle power transfer requires material measurement physics, Newton's law, business, energy, torque, material elasticity, fluid, temperature, heat, and thermodynamics. On the subjects of maintenance of light electric vehicle requires only dynamic electrical materials, laws of magnetism, and alternating current electricity.

Physical material that is irrelevant to light vehicle techniques subjects does not mean to be eliminated or eliminated, but there are two possibilities to consider. The first possibility, the irrelevant material is a prerequisite before studying material that supports the material of physics, for example the wave material in the subject of physics is a prerequisite for studying alternating current electric material that supports lightweight vehicle techniques materials. The second possibility of irrelevant material to be given at the vocational school level but required as a support when continuing to college. For example, straight and circular motion materials are used to design product development. In preparing the material of SMK physics as a basic vocational course of course the government has considered its relevance to the field of vocational studied, so the compilation of the material refers to a certain rules and systematics that have been determined. That the educational curriculum should be comprehensive and responsive to social dynamics, relevant, not over-load and capable of accommodating diversity and technological progress [11]. 
The results of interviews with three vocational physics teachers showed that the amount of time allocation set in the curriculum document exceeds the number of effective days set by the school. The amount of time allocated for 14 basic physics competencies in a year is 128 hours of lesson, while the number of physics lessons in the academic year $2017 / 2018$ is only 108 hours of lessons. Consequently, there is an essential elementary physics competence as a basis for studying lightweight but non-conveyance techniques. Three basic competencies are dynamic electricity, laws of magnetism, and alternating current electricity. Though the three materials of physics is very necessary in the subject of maintenance of light electric vehicle. As a result automotive teachers should explain basic electrical materials first before explaining the basic competencies that exist in the subject of maintenance of light electric vehicle.

Table 2. Physical Test Result Data

\begin{tabular}{cccc}
\hline $\begin{array}{c}\text { The } \\
\text { highest } \\
\text { score }\end{array}$ & $\begin{array}{c}\text { The } \\
\text { lowest } \\
\text { score }\end{array}$ & Average & Completeness \\
\hline 85.00 & 12.50 & 46.67 & 9.09 \\
\hline
\end{tabular}

Overall the average Score of physics students was still low. However, when viewed from the score of each number, it indicated that there were some basic competencies that achieved high scores, namely on the basic competence of measurement, energy, efficiency, static fluids, thermodynamics, and dynamic electricity. The results of interviews with students revealed that most of them argued that the physical materials were contextual with automotive learning. In addition, the results of the analysis indicated that the basic competence used is a basic competency relevant to the automotive field. This suggested that students readily understood the concepts of physics if the material of physics is relevant to the automotive field, especially automotive practice. Students learned well on what interests them, and meaningful content is better learned and maintained than meaningless content (Sahid \& Yagbasan, 2012).

In other basic competencies, the score of student score was still low. The results of the interviews showed that students found it
The existence of unpublished physics material shows that the relevance of physics material with the competence of Light Vehicle Techniques (TKR) has not been fully fulfilled. As a solution the physics teacher must provide irrelevant subject matter in the form of task so that relevant physics material can be conveyed and can be the basis for the students to learn the theory and practice of TKR. Research shows that vocational school science teachers can choose relevant lesson content by integrating the vocational curriculum (Dikdasmen, 2017).

\subsection{Relevance of physics value of students with automotive ability}

The physics test results data of 99 students from three SMK in Pekalongan Regency are presented in table 2.

difficult to understand the less contextual physics with the automotive field being studied and assumed that such physics material could not be applied in automotive practice. This is in line with Hartini's opinion that students consider the subject of physics as a theory that can not be applied in the field of automotive and technology (Haritni, 2011).

The results of interviews conducted with automotive teachers indicated that students' physics skills affected automotive capabilities. This can be seen from students with high physical score that he was able to apply his physics to the automotive field, and vice versa. Meanwhile, conceptual understanding is an important part of the competencies and skills that students in engineering must have (Streveler et al, 2008).

\section{Conclusion}

Based on the principle of internal relevance, the subject matter of physics of SMK vocational competence of Light Vehicle Techniques (TKR) is not yet fully relevant for basic competence of TKR. Meanwhile, the physics tests results show that there is relevance between the physics abilities of students of vocational techniques with the ability of Light Vehicle Techniques.

\section{References}

Coenders, F. et al. (2010). Journal Science Teacher Education. 2(1), 535-557. 
Dikdasmen. (2017) Salinan dan Lampiran Surat Keputusan Dirjen Dikdasmen Nomor 130 Tahun 2017. Jakarta: Kementerian Pendidikan Dasar dan Menengah.

Hartini. P. (2011). Jurnal Penelitian Pendidikan. 1(2), 190-199.

Ibrahim, R. (2011). Kurikulum dan Pembelajaran. Jakarta: Raja Grafindo Persada.

Jatmoko, D. (2013). Jurnal Pendidikan Vokasi. 3(1), 1-13.

Maulana, F. and Winanti, E.T. (2016). Jurnal Kajian Pendidikan Teknik Bangunan .3(3), 165-171.

Peraturan Pemerintah. (2010). Salinan dan Lampiran Peraturan Pemerintah Nomor 17 Tahun 2010 tentang Pengelolaan dan Penyelenggaraan Pendidikan. Jakarta: Kementerian Pendidikan dan Kebudayaan.

Permendikbud. (2013). Salinan dan Lampiran Peraturan Menteri Pendidikan dan Kebudayaan Republik Indonesia
Nomor 64 Tahun 2013 tentang Standar Isi Pendidikan Dasar dan Menengah. Jakarta: Kementerian Pendidikan dan Kebudayaan.

Ramdani, SD et al. (2012). NOSEL. 1(1), 5664.

Sackey, S.M. and Bester, A. (2016). South African Journal of Industrial Engineering. 27(4), 101-114.

Sahin, E. and Yagbasan, R. (2012) Europen Journal of Physics, 33(1), 315-325.

Saolika, M.D, et al. (2012). Jurnal Pembelajaran Fisika. 1(3), 252-260.

Streveler, R.A. et al. (2008). Journal of Engineering Education. 97(1_, 279294

Triyono, M.B. (2017). Tantangan Revolusi Industri ke 4 (i4.0) bagi Pendidikan Vokasi. Makalah Seminar Nasional Vokasi dan Teknologi Bali, $28^{\text {th }}$ of October 2017

Wheelahan, L. (2015). Journal of Curriculum Studies. $\quad 47(6), \quad 750-762$. 